\title{
ANALYSIS OF PROGRAM OF BUSINESS CREDIT FOR SOCIETY AT PT BANK BRI
}

\author{
Mas Rasmini \\ Department of Business Administration Science \\ Faculty of Politics and Social Science, Padjadjaran University \\ Email:mas_rasmini@ymail.com
}

\begin{abstract}
The purpose of this study is to investigate the implementation of a credit program (KUR) in state-owned banks (KUR program of study at Bank Rakyat Indonesia Branch Office Majalaya). The method used is a qualitative method of data collection techniques through in-depth interviews and non-participant observation. Data analysis techniques, namely the reduction of data, display data and then drawing conclusions. While testing is done by triangulation of data and discussions with members of the research team.Results from the study showed that the implementation process of granting KUR fairly and efficiently. That is the process of credit supply is in accordance with the legislation in force, both legislation and circulars BRI. So even in terms of processing time relatively quickly with quite a lot of stages.
\end{abstract}

Keyword : program of business credit for society

\section{ANALISIS PROGRAM KREDIT USAHA RAKYAT (KUR) PADA PT BANK BRI}

\begin{abstract}
ABSTRAK
Tujuan dari penelitian ini adalah untuk mengetahui implementasi program kredit usaha rakyat (KUR) pada bank BUMN (studi pada program KUR Bank Rakyat Indonesia Kantor Cabang Majalaya). Metode penelitian yang digunakan adalah metode kualitatif dengan teknik pengumpulan data melalui wawancara mendalam dan observasi non partisipan. Tenik analisis data yaitu dengan reduksi data, data display kemudian penarikan kesimpulan. Sedangkan pengujian dilakukan dengan triangulasi data dan diskusi dengan anggota tim penelitian

Hasil dari penelitian menunjukkan adanya proses pelaksanaan pemberian KUR yang cukup baik dan efisien. Artinya proses pemberian kredit pada prinsipnya sesuai dengan perundang-undangan yang berlaku, baik undang-undang maupun surat edaran BRI. Begitu pun dari sisi waktu pemrosesan relatif cepat dengan tahapan yang cukup banyak.
\end{abstract}

Kata kunci: program kredit usaha rakyat 


\section{PENDAHULUAN}

Menurut Menteri Perdagangan (2012): “UKM merupakan peranan penting dalam melakukan kegiatan bisnis di suatu negara karena akan memberikan implikasi untuk keberlangsungan suatu negara. UKM ini harus terus terjaga dan dapat dilakukan secara berkesinambungan agar memberikan keuntungan untuk pendapatan suatu Negara". Dilain pihak penulis melihat adanya masalah yang sering dihadapi oleh UKM yaitu kesulitan modal. Tidak sedikit UKM yang berpotensi untuk bisa lebih maju, namun karena kendala tersebut menjadikan usahanya tidak berkembang.

Kebijakan pemerintah dewasa ini telah cukup menunjukkan keberpihakan pada usaha kecil dan menengah (UKM). Banyak upaya dan langkah-langkah pemerintah menyangkut pemberdayaan pada usaha kecil dan menengah dalam lima tahun terakhir ini. Kebijakan pemerintah untuk berpihak kepada UKM itu merupakan langkah yang sangat tepat guna membangkitkan perekonomian bangsa dan negara. Salah satu bentuk upaya pemerintah dalam mendukung perkembangan UKM yang sudah dijalankan yaitu pemberian bantuan Kredit Usaha Rakyat (KUR) kepada para pelaku UKM, dimana penyalurannya bekerja sama dengan beberapa bank. Berdasarkan sumber dari komite-kur.com (30/09/2014), Sampai bulan September 2014, bank nasional yang menyalurkan KUR sebanyak 7 (tujuh) bank yaitu Bank Nasional Indonesia (BNI), Bank Rakyat Indonesia (BRI), Bank Mandiri, Bank Tabungan Negara (BTN), Bank Bukopin, Bank Syariah Mandiri (BSM) dan Bank Negara Indonesia Syariah (BNI Syariah).

Relaksasi pengaturan KUR ini dilakukan dengan tetap menjaga dan memperhatikan tata kelola/governance serta prinsip kehatihatian/prudential banking. Seluruh sumber dana KUR merupakan dana bank, yang berasal dari dana masyarakat, bukan dana Pemerintah. Untuk itu ketentuan perbankan tetap berlaku dalam penyaluran KUR.
Realisasi penyaluran Kredit Usaha Rakyat (KUR) oleh enam bank pelaksana (BNI, Mandiri, BRI, BTN, Bukopin dan Bank Syariah Mandiri) mencapai hingga Rp. 17,5 triliun rupiah. Dari angka realisasi tersebut, KUR dinikmati oleh lebih dari 2400 usaha mikro dan kecil (UMK) dengan pinjaman rata-rata sebesar Rp. 7,18 juta dengan outstanding per 31 Januari 2010 sebesar Rp. 7,93 triliun.

Tahun 2010 pemerintah menargetkan alokasi Program KUR hingga Rp. 20 Trilyun. Bagaimana caranya agar rencana tersebut dapat direalisasikan oleh pemerintah? Berapa dana yang akan dialokasikan untuk lembaga penjaminan. Idealnya adalah Rp. 2 Trilyun karena perlu giring rasio 10 kali lipat menjadi Rp. 20 Trilyun.

Dana KUR memang terus di tingkatkan dari 2008 sampai dengan tahun 2010, namun demikian masih banyak UKMK yang belum dapat menerima/menikmati program tersebut. Program KUR dapat dikatakan sudah dilaksanakan cukup baik. Namun masih perlu dikaji guna untuk meningkatkan capaian dari tujuan utama program ini, hal tersebut ditandai dengan masih adanya UKM yang belum menerima program ini karena ketidaktahuan terhadap keberadaannya.

Sementara berdasarkan sumber http://komitekur.com/article-101-sebaran-penyaluran-kreditusaha-rakyat-periode-november-2007-september2014.asp realisasi KUR beserta NPL untuk setiap bank pelaksana/penyalur KUR per September 2014 Bank BRI adalah penyalur KUR terbesar dengan total plafond mencapai Rp. 110,06 triliun. Selain sektor ritel BRI juga menyalurkan KUR di sektor mikro yang masing-masing plafondnya sebesar Rp. 20,09 triliun dan Rp. 89,97 triliun, debiturnya 114.591 UMK dan 10.901.101 UMK, rata-rata kredit Rp. 175,4 juta/debitur dan Rp. 8,3 juta/debitur, serta NPL penyaluran masing-masing $3,4 \%$ dan 2,0\%. Selengkapnya untuk realisasi dan NPL bank lain yang menyalurkan KUR dapat dilihat pada tabel 1.1 di bawah ini: 
Tabel 1.1 Realisasi dan NPL Penyaluran KUR Bank Nasional (30 September 2014)

\begin{tabular}{|c|c|c|c|c|c|c|}
\hline \multirow{3}{*}{ NO } & \multirow{3}{*}{ BANK } & \multicolumn{4}{|c|}{ REALISASI PENYALURAN KUR } & \multirow{3}{*}{$\begin{array}{l}\text { NPL } \\
(\%)\end{array}$} \\
\hline & & Plafon & Outstanding & \multirow{2}{*}{ Debitur } & $\begin{array}{l}\text { Rata-rata } \\
\text { Kredit }\end{array}$ & \\
\hline & & (Rp juta) & (Rp juta) & & (Rp juta) & \\
\hline 1 & BNI & $15,238,602$ & $3,478,169$ & 215,178 & 70.8 & 3.8 \\
\hline 2 & BRI (KUR Ritel) & $20,094,974$ & $7,616,531$ & 114,591 & 175.4 & 3.4 \\
\hline 3 & BRI (KUR Mikro) & $89,971,641$ & $23,226,308$ & $10,901,101$ & 8.3 & 2.0 \\
\hline 4 & BANK MANDIRI & $16,857,192$ & $6,654,876$ & 382,124 & 44.1 & 3.9 \\
\hline 5 & BTN & $4,567,269$ & $1,715,613$ & 25,104 & 181.9 & 11.9 \\
\hline 6 & BUKOPIN & $1,810,662$ & 528,715 & 12,114 & 149.5 & 5.4 \\
\hline 7 & $\begin{array}{l}\text { BANK SYARIAH } \\
\text { MANDIRI }\end{array}$ & $3,871,659$ & $1,278,982$ & 59,164 & 65.4 & 20.0 \\
\hline 8 & BNI SYARIAH & 306,019 & 140,676 & 1,376 & 222.4 & 2.9 \\
\hline & TOTAL & $152,718,020$ & $44,639,870$ & $11,710,752$ & 13.0 & 3.6 \\
\hline
\end{tabular}

Sumber: http://komite-kur.com/article-101-sebaran-penyaluran-kredit-usaha-rakyat-periodenovember-2007-september-2014.asp

\section{Rumusan Masalah Penelitian}

Intisari dari paparan pada latar belakang dapat dirumuskan permasalahan sebagai berikut: "Bagaimana Implementasi Program Kredit Usaha Rakyat (KUR) Pada Bank BUMN (studi Pada program KUR Bank BRI Cabang Majalaya)".

\section{Tujuan Penelitian}

Bertitik tolak dari latar belakang dan perumusan masalah, penelitian ini bertujan untuk "mempelajari dan mengetahui Implementasi Program Kredit Usaha Rakyat (KUR) Pada Bank BUMN (studi program KUR Pada Bank BRI Cabang Majalaya)".

\section{TINJAUAN PUSTAKA}

\section{Kredit}

Banyak definisi-definisi yang ditulis oleh beberapa ahli mengenai pengertian/batasan tentang kredit al. :

1. Kredit adalah "merupakan penyaluran dana dari pihak pemilik dana kepada pihak yang memerlukan dana". (Ismail, 2010:93)
2. Kredit adalah "aset yang akan menghasilkan pendapatan bunga dan atau keuntungan atas dasar bagi hasil"(Mandala, 2004:183). Selanjutnya dikatakan Mandala, karen kredit adalah aset yang menghasilkan pendapatan, maka porsi kredit dalam aset perbankan sangat dominan. Dalam ondisi normal kredit bank bisa mencapai sampai $70 \%$ total aset.

3. Dalam bahasa latin "kredit disebut "credere" yang artinya percaya. Maksudnya si pemberi kredit percaya kepada si penerima kredit, bahwa kredit yang disalurkannya pasti akan dikembalikan sesuai perjanjian. Sedangkan bagi penerima kredit berarti menerima kepercayaan, sehingga mempunyai kewajiban untuk membayar kembali pinjaman tersebut sesuai dengan jangka waktunya" (Kasmir, 2010:101)

4. Kredit adalah sistim keuangan untuk memudahkan pemindahan modal dari pemilik kepada pemakai dengan pengharapan memperoleh keuntungan, kredit diberikan berdasarkan kepercayaan orang yang memberikannya terhadap kecakapan dan kejujuran peminjam 
5. “...Kredit itu adalah suatu pemberian prestasi yang balas prestasinya (kontra prestasi) akan terjadi suatu waktu dihari yang akan datang..." (Amir Rajab Batubara dalam Kasmir, 2010:93)

6. "Kredit adalah penyediaan uang atau tagihan yang dapat dipersamakan dengan itu, berdasarkan persetujuan atau kesepakatan pinjam-meminjam antara bank dengan pihak lain yang mewajibkan pihak peminjam untuk melunasi utangnya setelah jangka waktu tertentu dengan pemberian bunga" (UU No.10 Tahun 1998 tentang Perbankan)

Pengertian-pengertian kredit di atas menurut penulis dapat diartikan bahwa kredit merupakan penyediaan dana oleh bank yang diperoleh dari deposan untuk yang memerlukan dana berdasarkan kesepakatan pinjam meminjam yang mewajibkan pihak peminjam untuk melunasi kewajibannya sesuai dengan perjanjian yang sudah disepakati.

Meskipun banyak pengertian mengenai kredit yang ditulis sebagaimana tersebut di atas, namun sebagai landasan yang menjadi pegangan adalah definisi kredit sesuai UU no.10 tahun 1998 tentang perbankan.

Pemberian kredit merupakan kegiatan utama bank, dan sekaligus merupakan sumber pendapatan untuk menutup biaya bunga yang diberikan kepada para nasabah simpanan dan biaya-biaya operasional, sementara dana lebih dari bunga kredit yang diperoleh setelah dipotong biaya bunga simpanan dan biaya-biaya operasional merupakan keuntungan bagi bank. Oleh sebab itu pemberian kredit merupakan kegiatan bisnis bagi bank dan berada dalam lalu lintas bisnis bagi bank serta merupakan tindakan kepengurusan bagi direksinya.

Ketentuan Undang-Undang Perbankan yang berkaitan dengan pemberian kredit terdapat beberapa pasal, diantaranya adalah:
1. Pasal 2 UU Perbankan yang menetapkan bahwa "Perbankan Indonesia dalam melakukan usahanya berasaskan demokrasi ekonomi dengan menggunakan prinsip kehati-hatian".

2. Pasal 4 UU Perbankan yang menetapkkan bahwa "Perbankan Indonesia bertujuan menunjang pelaksanaan pembangunan nasional dalam rangka meningkatkan pemerataan, pertumbuhan ekonomi, dan stabilitas nasional kearah peningkatan kesejahteraan rakyat banyak".

3. Pasal 8 UU Perbankan yang menetapkan bahwa "Bank Umum wajib mempunyai keyakinan berdasarkan analisis yang mendalam atas iktikad dan kemampuan serta kesanggupan Nasabah Debitur untuk melunasi utangnya atau mengembalikan pembiayaan dimaksud sesuai dengan yang diperjanjikan".

4. Pasal 29 Ayat 2 UU Perbankan yang menetapkan bahwa "Bank wajib memelihara tingkat kesehatan bank sesuai dengan ketentuan kecukupan modal, kualitas aset, kualitas manajemen, likuiditas, rentabilitas, solvabilitas, dan aspek lain yang berhubung-an dengan usaha bank, dan wajib melakukan kegiatan usaha sesuai dengan prinsip kehati-hatian".

5. Pasal 29 Ayat 3 UU Perbankan yang menetapkan bahwa "Dalam memberikan kredit atau pembiayaan berdasarkan Prinsip Syariah dan melakukan kegiatan usaha lainnya, bank wajib menempuh cara-cara yang tidak merugikan bank dan kepentingan nasabah yang mempercayakan dananya kepada bank".

6. Pasal 49 Ayat terutama 2(a) UU Perbankan yang menetapkan bahwa "Anggota Dewan Komisaris, Direksi atau pegawai bank yang dengan sengaja: a. meminta atau menerima, mengizinkan atau menyetujui untuk menerima suatu imbalan, komisi, uang tambahan, pelayanan, uang atau barang 
berharga, untuk keuntungan pribadinya atau untuk keuntungan keluarganya, dalam rangka mendapatkan atau berusaha mendapatkan bagi orang lain dalam memperoleh uang muka, bank garansi, atau fasilitas kredit dari bank, atau dalam rangka pembelian atau pendiskontoan oleh bank atas surat-surat wesel, surat promes, cek, dan kertas dagang atau bukti kewajiban lainnya, ataupun dalam rangka memberikan persetujuan bagi orang lain untuk melaksanakan penarikan dana yang melebihi batas kreditnya pada bank".

Fungsi pokok kredit pada dasarnya ialah pemenuhan jasa untuk melayani kebutuhan masyarakat (to serve the society) dalam rangka mendorong dan melancarkan perdagangan, mendorong melancarkan produksi, jasa-jasa dan bahkan konsumsi yang kesemuanya itu pada akhirnya ditujukan untuk meningkatkan taraf hidup manusia.

Perencanaan penyaluran kredit menurut Lukman (2005:73) harus dilakukan secara realistis dan obyektif agar pengendalian dapat berfungsi dan tujuan tercapai, perencanaan penyaluran kredit harus didasarkan kepada keseimbangan antara jumlah, sumber dan jangka waktu dana agar tidak menimbulkan masalah terhadap tingkat kesehatan bank.

Proses/Siklus pemberian kredit bank menurut Lukman meliputi hal-hal sebagai berikut:

1. Permohonan Kredit

Lukman (2005:74) mengatakan bahwa kegiatan tahap permulaan dengan maksud untuk saling bertukar informasi dasar antara calon debitur dan Bank terutama calon debitur yang baru pertama kali menagajukan fasilitas kredit kepada bank. Permohonan kredit yang diajukan umumnya dilakukan dengan menyampaikan dokumendokumen seperti : Surat permohonan resmi; Akte pendirian perusahaan sekaligus menjelaskan siapa yang berwenang meminta kredit, penerima kredit dan penanggungjawab pelunasan kredit; penjelasan rencana usaha atau potensi usaha; laporan keuangan perusahaan; informasi-informasi lain seperti NPWP, KTP, Surat-surat Izin yang telah diperoleh dalam rangka pembangunan bisnis yang telah berjalan.

Dalam permohonan tersebut calon debitur juga diminta mengisi berbagai formulir yang sudah disiapkan sesuai standar baku oleh bank untuk melengkapi hal-hal yang disampaikan calon debitur. Formulir tersebut bermacam-macam tergantung pada: jenis proyek, sektor industri, jenis kredit yang diminta, besarnya biaya proyek, besarnya jumlah kredit yang diminta, dan apakah akan dibiayai satu bank atau melalui kerja sama kredit sindikasi.

\section{Analisis kredit (Credit analysis)}

Lukman (2005:75) mengatakan bahwa setelah permohonan kredit diterima oleh bank (biasanya yang menerima adalah accaount officer/wirakredit atau kepala bagian kredit), maka calon debitur diminta untuk memberi keterangan-keterangan tambahan yang dapat menjelaskan isi dari berbagai dokumen yang disampaikannya kepada bank. Keterangan-keterangan tersebut bisa disampaikan secara lisan melalui wawancara maupun tertulis sesuai dengan informasi maupun data yang diminta oleh AO dari bank.

Selanjutnya, AO melakukan analisis yang mendalam tentang keadaan usaha/proyek pemohon kredit berdasarkan pedoman (manual) yang sudah ditentukan oleh bank dan biasanya tergantung kepada jenis kredit yang diminta.

Secara umum analisis kredit dilakukan berdasarkan dua metode yaitu:

1) Metode penilaian " $5 \mathrm{C}$ " yaitu meliputi:
a. Caracter,
b. Capacity,
c. Capital,
d. Condition, dan
e. Collateral. 
2) Metode penilaian " $6 \mathrm{~A}$ " yaitu meliputi:
a. Aspek Management dan organisasi
b. Aspek Pemasaran (Marketing)
c. Aspek Teknis (Tecnical)
d. Aspek Keuangan (Financial)
e. Aspek Yuridis/Hukum (Legal)
f. Aspek Sosial Ekonomi (Social and Economics)

3. Persetujuan Kredit

Analisis kredit (Lukman, 2005:75) yang dibuat oleh AO diperiksa dahulu oleh atasannya, kepala bagian kredit sebelum disampaikan kepada direksi bank. Nama dari laporan analisis kredit bermacammacam tergantung pada sistem dan prosedur yang dimiliki bank, antara lain sebagai berikut:

a. Laporan analisis kredit

b. Laporan analisis permohonan kredit

c. Laporan rekomendasi kredit

d. Dan lainnya

Atas dasar laporan analisis kredit di atas, pembahasan dan persetujuan kredit dilakukan oleh lembaga yang mungkin berbeda-beda, tergantung pada sistem dan prosedur yang berlaku pada masing-masing bank. Lembaga-lembaga itu antara lain sebagai berikut:

a. Kepala cabang, misalnya untuk njumlah kredit sampai dengan Rp 500 juta

b. Kepala wilayah, misalnya untuk kredit sampai dengan Rp 750 juta

c. Dan setrusnya

4. Perjanjian Kredit

Perjanjian kredit/akad kredit (Lukman, 2005:76) dipersiapkan oleh seorang notaris publik yang ditunjuk bankatau dipilih oleh calon nasabah (atau atas dasar kesepakatan bersama antara bank dan calon nasabah). Bank mengirim ahli hukumnya untuk mendampingi AO dalam membahas berbagai ketentuan yang harus dimuat dalam perjanjian kredit.

Ketentuan-ketentuan tersebut sebagian besar diambil dari hasil analisis kredit yang dituangkan dalam laporan analisis kredit yang telah disetujui. Secara umum isi perjanjian kredit yang dibuat oleh notaris berdasarkan masukan dari pihak bank adalah pihak pemberi kredit; pihak penerima kredit; tujuan pemberian kredit; besarnya biaya proyek, termasuk investasi tetap, kebutuhan modal kerja dan sebagainya; besarnya kredit yang akan diberikan bank; biaya-biaya lain yang harus dibayar oleh calon debitur, misal provisi kredit, appraisal fee, dan lain-lain; jangka waktu pengembalian kredit; jadwal pembayaran angsuran kredit dan pembayaran bunga kredit; jaminan kredit; syarat-syarat yang harus dipenuhi; kewajiban-kewajiban yang harus dilakukan oleh kreditur selama kredit belum dilunasi, misal menyampaikan laporan produksi, laporan penjualan, laporan keuangan dan lain-lain; dan hak-hak bank selama kredit belum dilunasi.

Perjanjian kredit tersebut ditandatangani oleh tiga pihak yaitu bank, nasabah dan notaris serta dicatat dan didaftarkan oleh notaris pada pengadilan negeri yang sesuai dengan domisili bank pemberi kredit sehingga mempunyai kekuatan hukum yang mengikat semua pihak.

5. Pencairan Kredit

Pencairan kredit (Lukman, 2005:78) dapat dilakukan oleh bank apabila calon debitur sudah memenuhi berbagai persyaratan seperti dituangkan dalam perjanjian kredit.

Persyaratan untuk pencairan kredit tersebut umumnya meliputi hal-hal sebagai berikut:

a. Perjanjian kredit sudah ditandatangani kedua belah pihak

b. Penarikan kredit sudah sesuai dengan kebutuhan proyek/usaha

c. Penarikan kredit sudah sesuai dengan jadwal pembangunan proyek/usaha

d. Permohonan pencairan kredit didukung oleh dokumen-dokumen yang sesuai dengan kebutuhan pencairan kredit

e. Besarnya kredit harus sesuai dengan perbandingan/rasio yang disepakati 
antara dana yang bersumber dari debitur dan pembiayaan dari bank

Pencairan kredit/pembayaran oleh bank dilakukan dengan berbagai cara, ada yang langsung dikirimkan ke rekening debitur dan ada pula yang dikirimkan ke rekening perusahaan yang menjadi rekanan debitur.

6. Pengawasan Kredit (Credit supervision)

Tahap ini menurut penulis merupakan tahap yang paling sukar untuk dilaksanakan apalagi kalau kondisi usaha debitor sedang mengalami penurunan/kurang menguntungkan.

Lukman (2010:79) menyampaikan bahwa pengawasan kredit yang dijelaskan/dimaksud adalah pengawasan yang dilakukan bank setelah kredit dicairkan. Pengawasan kredit merupakan salah satu kunci utama dari keberhasilan pemberian kredit, selain ketajaman dan ketelitian yang dilakukan sewaktu melakukan analisis kredit. Terjadinya kemacetan kredit utamanya disebabkan oleh kelalaian bank dalam melakukan pengawasan.

Pengawasan kredit menurut Lukman meliputi:

a. Adanya administrasi kredit yang memadai dan menggunakan cara-cara mutakhir, seperti penggunaan komputer, on line system dan lain sebagainya.

b. Keharusan bagi debitur untuk menyampaikan laporan secara berkala yang meliputi, laporan produksi, laporan penjualan, laporan utang dan piutang perusahaan, laporan keuangan dan lain-lain.

c. Keharusan bagi AO untuk melakukan unjungan ke perusahaan ataupun proyek yang dibiayai bank

d. Adanya konsultasi yang tersetruktur antara pihak bank dengan debitur, terutama pada saat debitur mulai mengalami kesulitan dalam bisnisnya atau telah menunjukkan tanda-tanda kemungkinan terjadinya kemacetan. e. Adanya suatu "sistem peringatan" pada administrasi bank yang pada umumnya dikelola oleh AO mengenai kondisi usaha debitur yang bersangkutan. Peringatan dini ini memperlihatkan kkepada AO mengenai informasi tentang kepatuhan nasabah kredit terhadap ketentuan yang telah dibuat dalam perjanjian kredit, misalnya posisi debitur berdasarkan kolektibitas kreditnya pada setiap waktu apakah debitur masih tergolong kredit lancar, ataukah sudah menjadi kredit kurang lancar, atau bahkan sudah termasuk kredit macet.

Sementara munurut ahli lain fungsi pengawasan dalam pelaksanaan kredit dibagi dua, al.

a. Pengawasan Preventif: yaitu sikap kehati-hatian dan akurasi pada tahaptahap awal mulai persiapan, analisa keputusan dan pelaksanaan pengadministrasian sebelum kredit dicairkan. Hal ini sesuai dengan UU No 10 Tahun 1998 tentang Perbankan Pasal 2, Pasal 29 Ayat (2) dan Pasal 49 ayat 2(b)

b. Pengawasan Represif: yaitu tugas pengawasan dan pembinaan setelah kredit cair dan dinikmati oleh debitur, hal tersebut pada dasarnya merupakan upaya pengamanan kredit dengan jalan memonitor dan mengikuti jalannya usaha serta memberikan saran serta konsultasi agar usaha debitur berjalan dengan baik, sehingga pengembalian kredit dapat berjalan dengan baik, pengawasan bisa dilakukan dengan 2 cara al. sebagai berikut :

1. Secara pasif

Dengan mewajibkan debitor memberikan laporan perkembangan usahanya baik insidentil maupun periodik. 
2. Secara aktip

Petugas melakukan supervisi langsung mendatangi tempat usaha debitur (on the spot), dan mengadakan pemeriksaan atas kebenaran penggunaan kredit, memeriksa stok persediaan barang dan lain-lain.

\section{Pelunasan Kredit}

Dalam kondisi yang ideal (Lukman, 2005:80), debitur akan dapat selalu memenuhi kewajibannya terhadap bank sesuai dengan kesepakatan yang dimuat dalam perjanjian kredit. Debitur dapat membayar angsuran pokok pinjaman beserta bunganya sesuai dengan jadwal yang telah dibuat, sehingga pinjaman/kredit bank akhirnya dinyatakan lunas

Dalam hal ini agunan yang semula yang semula dipegang dan dikuasai oleh bank seluruhnya harus dikembalikan kepada debitur.

\section{Kredit Usaha Rakyat}

Tanggal 5 November 2007, Presiden meluncurkan Kredit Usaha Rakyat (KUR). Adapun Bank Pelaksana yang menyalurkan KUR ini adalah Bank BRI, Bank Mandiri, Bank BNI, Bank BTN, Bank Syariah Mandiri dan Bank Bukopin. KUR ini merupakan fasilitas pembiayaan yang dapat diakses oleh UKM dan Koperasi terutama yang memiliki usaha yang layak namun belum bankable. UKM dan Koperasi yang diharapkan dapat mengakses KUR adalah yang bergerak di sektor usaha produktif antara lain: pertanian, perikanan dan kelautan, perindustrian, kehutanan dan jasa keuangan simpan pinjam.

Penyaluran KUR dapat dilakukan langsung, maksudnya UKM dan Koperasi dapat langsung mengakses KUR di Kantor Cabang atau Kantor Cabang Pembantu Bank Pelaksana. Untuk lebih mendekatkan pelayanan kepada usaha mikro, maka penyaluran KUR dapat juga dilakukan secara tidak langsung, dalam hal ini usaha mikro dapat mengakses KUR melalui
Lembaga Keuangan Mikro dan KSP/USP Koperasi, atau melalui kegiatan linkage program lainnya yang bekerjasama dengan Bank Pelaksana. (http://komitekur.com/f iles/kumpulan_peraturan_terbaru_kur.pdf)

Pengertian implementasi dan penjelasan mengenai program KUR di atas dapat memberikan informasi kepada penulis bahwa yang dimaksud dengan implementasi program KUR dapat diartikan sebagai kegiatan-kegiatan atau proses yang dinamis dari kebijakan pemerintah dalam menyalurkan dana kredit usaha rakyat kepada para UKM melalui Bank pelaksana dengan tujuan tercapainya UKM yang berkembang secara berkelanjutan

Ada beberapa peraturan perundangundangan yang menjadi landasan hukum Kredit Usaha Rakyat, yaitu:

1. Peraturan Presiden nomor 2 tahun 2008 tentang Lembaga Penjaminan,

2. Inpres 6 tahun 2007 tanggal 8 Maret 2007 tentang Kebijakan Percepatan Sektor Riil dan Pemberdayaan UKMK guna meningkatkan pertumbuhan ekonomi Indonesia,

3. MoU antara Departemen Teknis, Perbankan, dan Perusahaan Penjaminan yang ditandatangani pada tanggal 9 Oktober 2007,

4. Addendum I MoU Departemen Teknis, Perbankan, dan Perusahaan Penjaminan yang ditandatangani pada tanggal 14 Februari 2008,

5. Keputusan Menteri Koordinator Bidang Perekonomian nomor 5 tahun 2008 tentang Komite Kebijakan Penjaminan Kredit/Pembiayaan bagi UKMK,

6. Perjanjian Kerja Sama antara Bank Pelaksana dengan Lembaga Penjaminan,

7. Standar Operasional dan Prosedur Pelaksanaan KUR,

8. Addendum II MoU Departemen Teknis, Perbankan, dan Perusahaan Penjaminan yang ditandatangani pada tanggal 12 Januari 2010, 
9. Keputusan Menteri Koordinator Bidang Perekonomian Nomor : KEP07/M.EKON/01/2010 Tentang Penambahan Bank Pelaksana Kredit Usaha Rakyat,

10. Keputusan Deputi Bidang Koordinasi Ekonomi Makro dan Keuangan, Kementerian Koordinator Bidang Perekonomian Nomor : KEP01/D.I.M.EKON/01/2010 tentang Standar Operasional dan Prosedur Pelaksanaan Kredit Usaha Rakyat. (http://komitekur.com/landasan_hukum.asp)

11. Surat Edaran Direksi BRI Nose S.08DIR/ADK/03/2010 tanggal 4 Maret 2010 Tentang Kredit Usaha Rakyat (KUR) Ritel

12. Surat Edaran Direksi BRI Nose S.08dDIR/ADK/03/2010 tanggal 23 Mei 2013 Tentang Revisi Keempat Atas Ketentuan Kredit Usaha Rakyat (KUR) Ritel.

Pemerintah dalam hal ini berperan selaku penjamin kredit melalui PT. Askrindo dan Perum Jamkrindo. Sementara BRI sebagai pelaksana program memiliki wewenang dalam hal penentuan syarat yang harus dipenuhi oleh calon penerima KUR tanpa mengabaikan ketentuan dasar dari pemerintah seperti yang telah diuraikan di atas. Sementara syarat dan peraturan yang harus dipenuhi dan dipatuhi oleh penerima program yaitu peraturan atau ketentuan-ketentuan perbankan yang berlaku di BRI, hal ini sesuai dengan ketetapan pemerintah bahwa seluruh sumber dana KUR merupakan dana bank, yang berasal dari dana masyarakat, bukan dana Pemerintah. Untuk itu ketentuan perbankan tetap berlaku dalam penyaluran KUR. Sehingga apabila diketahui ada penyimpangan yang dilakukan oleh penerima program maka Bank BRI berhak memberikan sanksi sesuai dengan ketentuan yang telah disepakati bersama penerima program.

Pemerintah merupakan pemegang kebijakan mengenai pelaksanaan Program KUR, sudah tentu akan mengawasi jalannya program ini yang dilaksanakan oleh para pelaksana Program agar dana KUR diberikan tepat kepada sasaran program. Sementara BRI sebagai pelaksana program akan melaksanakan tugas ini sesuai dengan prosedur yang ditetapkan dalam perjanjian antara pemerintah dengan BRI, yang mana salah satunya adalah cermat dalam menentukan UKM yang akan menerima program. Disisi lain UKM sebagai penerima program bisa memanfaatkan bantuan tersebut dengan cara pengelolaan yang baik, benar-benar digunakan untuk kebutuhan usahanya dan senantiasa disiplin dalam memegang amanah dan tanggung jawab, sehingga dari rangkaian pelaksanaan program tersebut diharapkan UKM dapat tetap beroperasi dan bisa mengembalikan dana bantuan tersebut dengan lancar, lebih jauhnya bisa terus berkembang secara berkelanjutan.

\section{METODE PENELITIAN}

\section{Metode Penelitian}

Metode penelitian yang digunakan untuk mengetahui bagaimana implementasi program KUR pada Bank BUMN yaitu dengan menggunakan metode penelitian kualitatif. Melalui pendekatan kualitatif ini diharapkan dapat diperoleh informasi mendalam mengenai implementasi program KUR pada Bank UMUM.

Jenis penelitian yang digunakan oleh peneliti adalah jenis penelitian deskriptif.

\section{Informan}

Penelitian dengan menggunakan metode kualitatif tidak menggunakan istilah populasi namun dengan istilah social situation begitupun dengan sumber pemberi informasi tidak menggunaan istilah responden namun dengan istilah nara sumber atau informan.

Adapun informan dalam penelitian ini adalah Manajer Pemasaran yaitu Bapak Puad untuk KUR Ritel, Bapak Adi dan Bapak Tutun sebagai Asisten Manajer Bisnis Mikro, Bapak Anton sebagai Kepala Unit BRI Cicalengka, Bapak Agus sebagai Kepala Unit BRI Maruyung, Bapak Doni dan Ibu Marina sebagai 
Accaount Officer KUR Ritel, dan Bapak Billi sebagai mantri (Analis) untuk KUR Mikro. Mengingat sebagai pelaksana program KUR yang menjalankan pelaksanaan pemberian KUR kepada sasaran program terpilih, tentunya tahu banyak bagaimana situasi pada saat proses pelaksanaan berjalan. Dan yang terakhir untuk mengetahui sejauhmana program ini dapat dirasakan manfaatnya oleh penerima program maka diambil informan pendukung dari dua UKM penerima program yaitu Bapak Aep merupakan Nasabah KUR Ritel dan Ibu Erika Anggreka merupakan nasabah KUR Mikro.

\section{Teknik Pengumpulan Data}

Penulis menggunakan wawancara mendalam (in depth interview), studi dokumentasi, dan trianggulasi dalam proses pengumpulan data pada penelitian ini, dengan penjabaran sebagai berikut :

1. Wawancara Mendalam (in depth interview)

2. Observasi partisifasi pasif

3. Studi Dokumen

\section{Analisis Data}

Analisis data pada penelitian ini mengacu pada model analisis data kualitatif dari Miles dan Huberman. Menurut Miles dan Huberman dalam Sugiyono (2007 : 91), analisis ini meliputi tiga langkah, yaitu :

1. Data reduction (Reduksi data)

2. Data display (Penyajian data)

3. Conclusion drawing/verification (Menarik kesimpulan/verifikasi)

\section{Pengujian Kredibilitas Data}

Data-data atau temuan dalam penelitian kualitatif dinyatakan valid apabila tidak ada perbedaan antara yang dilaporkan peneliti dengan apa yang sesungguhnya terjadi pada obyek yang diteliti. Untuk itu diperlukan uji nilai kebenaran (uji kredibilitas) terhadap data yang didapatkan. Pengujian kredibilitas data penelitian dilakukan dengan cara :

1. Trianggulasi
2. Pengarahan dari Kepala Cabang dan Manajer Perkreditan BRI Majalaya

\section{HASIL PENELITIAN DAN PEMBAHASAN}

\section{Implementasi Program KUR di Kantor BRI Cabang Majalaya}

Implementasi merupakan tindakan-tindakan yang dilakukan baik oleh individu-individu atau pejabat-pejabat atau kelompok-kelompok pemerintah atau swasta yang diarahkan pada tercapainya tujuan-tujuan yang telah digariskan dalam keputusan kebijaksanaan" (Van Meter dan Van Horn dalam Leo Agustino, 2006:139) sementara yang dimaksud dengan Implementasi menurut BRI melalui penjelasan dari beberapa tim manajemen dan pengawas internal khususnya implementasi KUR adalah pelaksanaan program KUR oleh BRI mulai dari sosialisasi program KUR, pengajuan permohonan, analisa calon debitur, rekomendasi dari analis, keputusan, pencairan dana KUR, sampai pada tahap pengawasan.

Program KUR yang disalurkan oleh BRI Kantor Cabang Majalaya terbagi menjadi 2 (dua) jenis kredit yaitu KUR ritel dan KUR mikro. KUR Ritel dilaksanakan langsung oleh BRI Kantor Cabang di bawah Pimpinan Manajer Pemasara (MP) dan Pimpinan Cabang sebagai pemutus kredit dan KUR mikro dilaksanakan atau disalurkan oleh BRI Kantor Unit di bawah pengawasan Asisten Manajer Bisnis Mikro (AMBM) dan Kepala Unit sebagai pemutus. BRI adalah satu-satunya bank penyalur program KUR dengan 2 jenis kredit, diantara beerapa bank penyalur lainnya seperti BNI, Bank Mandiri, Bank Bukopin dan lainlain.

Tujuan Program KUR dibagi kedua jenis yaitu KUR Ritel dan KUR Mikro, yaitu agar program KUR bisa tersalurkan sampai kepada para pelaku usaha mikro yang ada di daerah. Hal tersebut menurut pendapat dari Asisten Manajer Bisnis Mikro dipandang perlu 
dilakukan oleh BRI untuk mencapai tujuan dari Program KUR itu sendiri yaitu menumbuhkembangkan usaha-usaha mikro kecil menengah dan koperasi. Baik program KUR Ritel maupun program KUR Mikro dilihat dari penggunaannya terdiri dari:

1. kredit modal kerja (KMK) dan

2. kredit investasi.

Sampai tahun 2014 ini berdasarkan informasi dari para informan sebagian besar KUR yang tersalur adalah kredit modal kerja. Berdasarkan data sekunder dari Manajer Pemasaran menunjukkan bahwa KMK yang berhasil disalurkan sampai dengan bulan Oktober tahun 2014 mencapai Rp 23.105.726.477 sedangkan KI yang berhasil disalurkan hanya mencapai Rp 4.621.145.295 atau hanya mencapai $20 \%$ dari total KMK yang tersalur.

Sementara dilihat dari jenis usahanya baik KUR Ritel maupun KUR Mikro terdiri dari:

1. Kredit Pertanian

2. Kredit Perdagangan

3. Perindustrian

4. Jasa

Pada realisasinya sebagian besar KUR Ritel memdanai usaha perdagangan, sementara KUR Mikro mendanai keduanya.

Program KUR ritel dan Program KUR mikro di BRI Kantor Cabang Majalaya pada tahapan pelaksanaannya tidak ada yang berbeda, dari tahapan sosialisasi sampai dengan pengawasan sama, hanya pelaksana/pemutus dari kedua program tersebut yang berbeda seperti telah dijelaskan di atas.

Suku bunga yang dibebankan baik pada KUR Ritel maupun KUR Mikro ditetapkan sama oleh pemerintah yaitu $13 \%$ per tahun. Suku bunga ini lebih kecil dari produk kredit BRI sendiri yaitu Kredit Ritel Komersial yang ditetapkan BRI sebesar 14 \%. Suku bunga KUR yang relatif kecil ini ditetapkan pemerintah dengan maksud untuk meringankan beban kredit debitur.

\section{Implementasi KUR Ritel}

KUR Ritel sampai saat ini menurut MP dan AO pada prinsipnya sudah berjalan dengan baik. Hal ini tidak terlepas dari proses pelaksanaan KUR yang baik pula. Proses pemberian KUR kepada nasabah di Kanca BRI majalaya mengikuti tahapan yang sudah ditetapkan oleh Kantor Pusat BRI yang ada dijakarta. Adapun tahapan yang dilaksanakan yaitu mulai dari sosialisasi program, pengajuan permohonan kredit oleh calon debitor/peminjam, analisa kredit, rekomendasi analis, keputusan kredit, Pelaksanaan/Akad dan administrasi kredit dan terakhir pengawasan.

\section{Sosislisasi Program KUR}

Para informan pada prinsipnya memberikan informasi yang sama mengenai sosialisasi Program KUR, yaitu dilaksanakan oleh Tim Pemasaran di bawah Pimpinan Manajer Pemasaran (MP) untuk Program KUR Ritel. Memasarkan atau mensosialisasikan program KUR dilakukan dengan beberapa cara yaitu Brosur, Cross Selling, Kerja sama dengan dinas pemerintahan, dan Website BRI (www.bri.go.id).

Sampai saat ini diakui oleh BRI Kanca Majalaya bahwa sosialisasi masih sangat kurang dilakukan. Hal ini terjadi karena Program KUR sendiri merupakan program pemerintah sehingga pemerintah sendiri sudah melakukan sosialisasi secara maksimal, melalui media yang ada, yaitu Website BI, Media Masa dan Telivisi.

Kondisi tersebut sesuai dengan informasi yang didapat dari nasabah KUR, mereka mengatakan bahwa informasi program KUR sangat kurang. Masayarakat khususnya para pengusaha kecil banyak yang tidak mengetahui mengenai program ini.

\section{Pengajuan Permohonan KUR}

Pengajuan KUR oleh calon debitur KUR Ritel diajukan kepada BRI Kantor Cabang Majalaya yang ditujukan kepada Pimpinan Cabang (Pinca). Selanjutnya berkas pengajuan akan didisposisikan oleh Pinca ke bagian administrasi 
kredit (ADK) di cek kelengkapan persyaratan. Calon debitur pada saat mengajukan selain memberikan surat permohonan/pengajuan, mereka harus melampirkan syarat-syarat yang sudah ditetapkan BRI.

Berdasarkan teori pada tahap ini dilakukan wawancara kepada calon debitur untuk melihat karakter, dan mengumpulkan data awal mengenai usaha calon debitur. Sementara pada pelaksanaannya di Kanca BRI Majalaya, wawancara dilakukan pada saat pelaksanaan analisa (on the sport) oleh AO ke lapangan atau tempat usaha calon debitur. Hal ini dilakukan untuk mempersingkat waktu pada saat tahapan pengajuan (masukkan permohonan). Selama berkas-berkas permohonan di pelajari oleh ADK, AO melakukan wawancara pada tahapan Analisa/penilaian kredit. Sehingga proses pemeriksaan berkas pengajuan kredit tidak terlalu lama.

Senada dengan informasi yang diperoleh dari informan debitur KUR Ritel bahwa pada saat dia menyerahkan berkas permohonan kredit, tidak dilakukan wawancara mendalam mengenai kondisi usaha atau pun hal lainnya. Debitur mengatakan baru diwawancara pada saat AO mendatangi atau mensurvei tempat usahanya.

\section{Analisa Calon Debitur}

Analisa dilakukan oleh AO langsung ke tempat usaha calon debitur. Prinsip kehati-hatian diterapkan oleh AO pada waktu penilaian usaha, hal ini diterapkan dengan cara mewawancarai calon debitur. Informasi yang digali sesuai dengan teori yaitu dengan memperhatikan 5C: Character, Capacity (Kemampuan), Capital (Modal), Condition (Kondisi/Prospek Usaha), Collateral (Agunan), Aspek Hukum.

Data-data mengenai berbagai kondisi keuangan serta kemampuan debitur dalam menjalankan/mengelola usahan akan dijadikan dasar untuk menghitung prediksi kredit yang dibuthkan. AO dalam menghitung prediksi kebutuhan kredit bisa menggunakan dua pendekatan yaitu pendekatan RPC atau pendekatan WCTO. Pada prakteknya yang sering digunakan adalah pendekatan WCTO. Dari perhitungan ini akan muncul angka nominal rupiah yang aman untuk diberikan sebagai kredit usaha kepada calon debitur yang kemudian ini akan masuk dalam salah satu rekomendasi AO kepada pemutus kredit.

Pernyataan dari informan debitur menguatkan informasi di atas, mereka menyatakan bahwa usaha mereka disurvei terlebih dulu sebelum putusan kredit dikeluarkan oleh BRI Kanca Majalaya, pertanyaan yang diajukan seputar kepemilikan usaha, omset, laba kotor, agunan dan hal lainnya. BRI dipandang oleh debitur dari segi kehati-hatiannya sudah cukup bagus, hal ini dialami oleh debitur dengan adanya beberapa pertanyaan yang diajukan pada saat wawancara di kegiatan survei tersebut.

\section{Memorandum Analisis Kredit dan Rekomendasi Kredit}

Memorandum Analisis Kredit (MAK) dan Rekomendasi Kredit yang diberikan AO (Pemrakarsa) kepada pemutus akan tergantung dari jumlah plafon kredit yang direkomendasikan, kalau besarnya plafon kredit sampai dengan Rp 300.000.000,- maka rekomendasi diberikan kepada Manajer Pemasaran. Namun apabila plafon kredit yang direkomendasikan di atas Rp 300.000.000,sampai dengan Rp 500.000.000,- maka rekomendasi diserahkan kepada Pimpinan Cabang.

Memorandum Analisis Kredit merupakan output tertulis dari hasil analisis pada tahap ketiga di atas yang dibuat oleh AO. Memorandum Analisis Kredit akan dijadikan dasar untuk pembuatan rekomendasi oleh $\mathrm{AO}$ (pemrakarsa), lengkap dengan tanda tangan AO.

\section{Keputusan}

MAK dan Rekomendasi AO diterima oleh pemutus (MP atau Pinca) kemudian diperiksa dan dipelajari kelengkapannya. Pada tahap ini 
pemutus dalam menjalankan dual kontrol, akan melakukan analisa (OTS) yang kedua, dimana objek yang dianalisa tidak berbeda dengan objek analisa yang dilakukan oleh AO. Setelah semua sudah dipandang cukup maka apabila pemutus mengabulkan permohonan kredit akan dikeluarkan surat putusan yang berisi persetujuan kredit dengan syarat harus membuka tabungan britama dan ditandatangani oleh pemutus kredit. Surat putusan akan di disposisi kepada pejabat ADK untuk dubuatkan operating letter (OL:Surat Penawaran Putusan Kredit) dan ditandatangani oleh Pemutus dan Pejabat ADK untuk kemudian dipelajari oleh calon debitur. Surat penawaran menurut informasi dari MP dapat dinegosiasikan dalam hal jangka waktu pinjaman. Namun sepanjang tahun 2014 menurut beberapa informan, belum ada kejadian dimana debitur menolak isi dari surat penawaran, mereka sepakat dan sebagai tanda persetujuan calon debitur suami istri mentandatangani surat penawaran tersebut.

\section{Pencairan Dana KUR (Akad)}

Sebelum dilakukan pencairan ada beberapa administratif yang harus diselesaikan yaitu penyerahan Surat Penawaran kepada Calon debitur, apabila mereka sepakat maka mereka menandatangani surat tersebut kemudian pada hari yang sama dilanjutkan dengan penandatanganan surat pengakuan hutang (SPH) yang dituangkan dalam surat persetujuan pinjam uang yang ditandatangani oleh pemutus dan debitur. Satu hal yang merupakan kebijakan internal BRI adalah dimana debitur harus membuat surat kuasa menjual kepa BRI uintuk menjual agunan yang dijaminkan apabila dikemudian hari terjadi kredit macet atau wan prestasi.

\section{Pengawasan}

Hasil dari wawancara dengan beberapa informan diperoleh informasi bahwa pengawasan terhadap kredit usaha rakyat, dilakukan dengan dua cara yaitu pengawasan prevensif dan pengawasan represif.
Pendekatan yang digunakan pada saat pengawasan dilakukan adalah pendekatan kekeluargaan, sehingga debitur pada saat diawasi tidak merasa terganggu, namun sebaliknya akan menjadi merasa nyaman dan terbuka dengan apa yang dihadapi oleh usahanya. Hal ini akan mempermudah petugas pengawas dalam menjalankan tugasnya yaitu ikut membina dan mengarahkan usaha ke arah yang lebih baik.

Dilihat dari sisi waktu, pengawasan dilakukan setelah 3 bulan dari pencairan sampai dengan kredit lunas, dilakukan tidak kaku, melainkan fleksible mengikuti kebutuhan dilapangan.

Informasi dari informan debitur menguatkan pernyataan/informasi dari informan BRI, bahwa mereka kerap dikunjungi petugas AO. Mereka sering sharing mengenai usahanya pada saat dikunjungi dan merasa sangat terbantu dengan masukan/arahan-arahan dari para AO tersebut. Bahkan karena begitu dekatnya para AO kepada debitur, debitur sudah merasa seperti keluarga sendiri. Jadi kalau ada masalah yang dihadapi oleh debitur mereka tidak sungkan-sungkan untuk menyampaikannya kepada AO.

Kondisi seperti ini sangat menguntungkan bagi pihak BRI dalam melakukan pengawasan langsung, karena dukungan data dari sifat tranparansi debitur sangat mudah diperoleh. Sehingga pencegahan dari keterlambatan atau kemacetan pembayaran angsuran bisa dilakukan sedini mungkin sebelum terjadi.

\section{Implementasi Program KUR Mikro}

Proses pemberian KUR kepada nasabah di Kanca BRI majalaya mengikuti tahapan yang sudah ditetapkan oleh Kantor Pusat BRI yang ada dijakarta. Demikian pula dengan proses pemberian KUR Mikro. Pada prinsipnya tahapan yang dilaksanakan oleh pemutus kredit beserta staf lininya adalah sama yaitu mulai dari sosialisasi program, pengajuan permohonan kredit oleh calon debitor/peminjam, analisa 
kredit, rekomendasi analis, keputusan kredit, Pelaksanaan/Akad dan administrasi kredit dan terakhir pengawasan. Namun pada teknisnya penyaluran kredit usaha rakyat mikro di kantor unit lebih sederhana dengan maksud untuk menghilangkan beban pengajuan kredit yang ditanggung calon debitur

Para informan (AMBM, Kepala Unit, Mantri) pada prinsipnya memberikan informasi yang sama mengenai sosialisasi Program KUR Mikro, yaitu dilaksanakan oleh semua jajaran kantor unit, mulai dari kepala unit, mantri, CS sampai pada satpam. Jadi intinya semua adalah pemasar. Adapun cara yang dilakukan tidak jauh berbeda dengan yang dilakukan tim KUR Ritel yaitu: Brosur, Website BRI (www.bri.go.id), dan Cross Selling. Sampai saat ini diakui oleh BRI Kantor unit Cicalengka dan Kantor unit Maruyung bahwa sosialisasi masih sangat kurang dilakukan. Hal ini terjadi karena Program KUR sendiri merupakan program pemerintah sehingga pemerintah sendiri sudah melakukan sosialisasi secara maksimal, melalui media yang ada, yaitu Website BI, Media Masa dan Telivisi.

Kondisi tersebut sesuai dengan informasi yang didapat dari nasabah KUR wilayah cicalengka dan beberapa masyarakat lainnya, mereka mengatakan bahwa informasi program KUR sangat kurang. Masayarakat khususnya para pengusaha kecil banyak yang tidak mengetahui mengenai program ini.

\section{Pengajuan Permohonan KUR}

Mulai dari pengajuan permohonan pinjaman KUR Mikro sampai dengan putusan dan pencairan kredit, hanya tertuang dalam satu berkas tertulis dan sah ditandangani oleh pihakpihak yang terkait. Pada tahap pengajuan calon debitur cukup mengisi poin pertama dalam lembaran tersebut yaitu aspek identitas nasabah dan usaha yang meliputi informasi nama pemohon, nama ibu kandung pemohon, nama suami/istri pemohon, status nasabah, nomor identitas diri, alamat rumah, jenis usaha/pekerjaan pemohon, lama usaha, lokasi/alamat usaha, lama menetap dilokasi usaha, keperluan kredit, jumlah dan jangka waktu kredit yang diajukan, dan jenis serta no rekening simpanan di BRI unit. Kemudian ditandatangani oleh pemohon, customer service dan disetujui oleh mantri.

Senada dengan yang disampaikan oleh debitur, bahwa mereka pada saat pengajuan dulu tidak banyak diminta persyaratan, dan hanya mengisi satu lembar berkas saja yang memuat data-data diri dan data usaha yang akan diajukan untuk mendapat dana KUR.

\section{Analisa Calon Debitur dan Rekomendasi Mantri}

Analisa dilakukan oleh Mantri langsung ke tempat usaha calon debitur. Prinsip kehatihatian diterapkan oleh AO pada waktu penilaian usaha, hal ini diterapkan dengan cara mewawancarai calon debitur. Informasi yang digali tetap sesuai dengan i dengan teori yaitu dengan memperhatikan 5C (character, capital, capacity, condition dan collateral). Namun menurut kepala unit dan mantri juga informasi dari AMBM, bagi calon debitur KUR Mikro tidak dilihat/diutamakan dalam jaminan. Karena memang dari aturan pemerintahnya tidak diharuskan memakai jaminan. Kalaupun ada yang punya barang untuk dijaminkan dan diambil oleh BRI, itu semata-mata hanya untuk menguatkan kepercayaan.

Informasi dari informan debitur menguatkan informasi di atas, bahwa mereka kerap ditanya mengenai kondisi penghasilan dan pengeluaran rutin perbulan baik dari usaha ataupun pengeluaran sehari-hari rumah tangga. Mereka mangakui tidak pernah membuat pembukuan dalam menjalankan usaha, sehingga tidak tahu persis penghasilan ataupun pengeluaran per bulannya. Penghasilan dan pengeluaran diketahui dengan bantuan mantri dalam mengidentifikasi perkiraan penerimaan dan pengeluaran per hari. 


\section{Daftar Agunan}

Daftar agunan, terdapat pada lembar yang sama dengan yang di atas, boleh diisi boleh juga tidak. Tergantung pada ada atau tidaknya barang/benda yang akan diagunkan. Secara formal dalam KUR Mikro agunan tidak diwajibkan. Namun mantri akan memeriksa dengan seksama apakah calon debitur memiliki atau tidak benda yang pantas untuk dijadikan agunan. Kalau ternyata calon debitur memilikya maka BRI melalui mantri akan memutuskan untuk mengambil bukti-bukti kepemilikan dari benda tersebut dan dijadikan sebagai agunan.

\section{Putusan dan Syarat Kredit serta Pencairan Kredit}

Setelah tabel rekomendasi dan agunan di isi oleh mantri sesuai dengan hasil analisa mantri di lapangan, kemudian diserahkan kepada pemutus kredit, dalam hal ini adalah kepala unit untuk dipelajari dan dipertimbangkan. Kedapatan pemutus sudah merasa cukup dari hasil rekomendasi yang mantri sampaikan maka pemutus bisa langsung memutuskan saat itu juga. Seandainya dari rekomendasi mantri masih ada yang diragukan maka kepala unit bersama-sama mantri melakukan analisa ulang (on the sport; OTS) kepada calon debitur untuk melihat kembali kondisi debitur dan usahanya guna menambah keyakinan dalam memutuskan pemberian kredit. Dan setelah pemutus yakin maka akan dikeluarkan putusan kredit. Hal ini senada dengan yang disampaikan debitur bahwa diantara mereka ada yang dikunjungi satu kali ada juga yang dikunjungi dua kali selama proses pemohonan kredit.

Putusan sudah keluar akan diajukan ke calon debitur. Apabila calon debitur setuju/sepakat maka pada hari yang sama kredit dapat dicairkan dan pembayaran oleh bank langsung masuk ke rekening debitur.

\section{Pengawasan}

Sesuai dengan informasi dari para informan KUR Ritel, Informan KUR Mikro pun menyatakan hal yang sama dimana pengawasan terhadap kredit usaha rakyat, dilakukan dengan dua cara yaitu pengawasan prevensif dan pengawasan represif.

Pendekatan yang digunakan pada saat pengawasan juga sama seperti yang dilakukan pada pengawasan KUR Ritel, yaitu pendekatan kekeluargaan, sehingga debitur pada saat diawasi tidak merasa terganggu, namun sebaliknya akan menjadi merasa nyaman dan terbuka dengan apa yang dihadapi oleh usahanya. Hal ini akan mempermudah petugas pengawas dalam menjalankan tugasnya yaitu ikut membina dan mengarahkan usaha ke arah yang lebih baik.

BRI dalam melakukan pengawasan berdasarkan prinsip kehati-hatian baik dalam pengawasan terhadap KUR Ritel maupun KUR Mikro, menurut penulis sudah sesuai dengan yang diamanatkan pada Pasal 2 UU Perbankan yang sudah disebutkan di atas dan Pasal 29 Ayat 2 UU Perbankan yang menetapkan bahwa "Bank wajib memelihara tingkat kesehatan bank sesuai dengan ketentuan kecukupan modal, kualitas aset, kualitas manajemen, likuiditas, rentabilitas, solvabilitas, dan aspek lain yang berhubung-an dengan usaha bank, dan wajib melakukan kegiatan usaha sesuai dengan prinsip kehati-hatian". Serta Pasal 49 ayat 2(b) UU Perbankan dengan menetapkan bahwa bank harus melaksanakan langkah-langkah yang diperlukan untuk memastikan ketaatan bank terhadap ketentuan dalam undang-undang ini dan ketentuan peraturan perundang-undangan lainnya yang berlaku bagi bank, diancam dengan pidana penjara sekurang-kurangnya 3 (tiga) tahun dan paling lama 8 (delapan) tahun serta denda sekurang-kurangnya Rp. 5.000.000.000,00 (lima miliar rupiah) dan paling banyak Rp. 100.000.000.000,00 (seratus miliar rupiah). 
Tingkat Keberhasilan Program KUR di BRI Kanca Majalaya

\section{Tingkat Keberhasilan Program KUR Ritel}

BRI tidak terlepas dari kekurangan-kekurangan dalam menjalankan pelaksanaan/implementasi kreditnya khususnya program KUR. Hal ini terlihat dari data NPL KUR Ritel per Oktober tahun 2014 mengalami kenaikkan yang cukup tinggi dimana sebelumnya (tahun 2013) NPL hanya 2,87 \% meningkat di tahun 2014 menjadi 8,74\%, ini kondisi dimana NPL jauh di atas standar yaitu 5\%. Kondisi ini sangat menuntut pihak BRI khususnya Manajer Pemasaran dan jajarannya untuk bekerja lebih keras lagi dalam mengembalikan kondisi kesehatan KUR Ritelnya. NPL naik berdasarkan informasi dari MP dan AO terjadi karena adanya kondisi yang tidak begitu baik dan mendukung terhadap jalannya usaha para debitur. Salah satunya adalah dimana kondisi perekonomian tahun 2014 yang kurang baik, memberikan efek yang cukup besar kepada para UKM.

Berdasarkan hasil survei tim Pemasaran BRI dari kondisi pasca pemilihan presiden dan polemik politik yang memanas berdampak terhadap kurang baiknya kondisi perekonomian, hal ini ditandai dengan adanya ketelatan beberapa supllier dalam mengirimkan barang kepada UKM, sehingga mengakibatkan sebagian besar UKM menjadi tersendat dalam proses produksi ataupun proses penjualan. Pada akhirnya beberapa dari mereka ada yang mulai tersendat pembayarannya dengan alasan putaran persedian dan tingkat penjualan yang menurun tidak bisa membuat mereka yakin dalam melakukan pembayaran kredit.

Kondisi ini tidak lantas membuat Tim Pemasaran BRI berkecil hati. Mereka berupaya terus untuk meningkatkan penyaluran kredit terutama Program KUR yang memang ditarget oleh pemerintah dan Kanpus BRI. Penyaluran KUR oleh BRI pada tahun 2014 masih tetap bisa dikatakan meningkat dibandingkan dengan tahun 2013, meskipun target 2014 sendiri sampai bulan oktober belum sampai pada target maksimal.

BRI memberikan beberapa indikator dalam mengukur keberhasilan program KUR Ritel oleh BRI Kanca Majalaya. Indikator yang dimaksud diantaranya:

1. Tingkat Penyerapan KUR

Di BRI secara Total penyerapan dana KUR Ritel dan KUR Mikro berada dalam kategori tinggi (data pada tabel 1) dibandingkan dengan Bank penyalur KUR lainnya. Di BRI Kanca Majalaya sendiri pada tahun 2014 meskipun NPL meningkat cukup tinggi namun penyaluran terus meningkat dari tahun 2013 sampai dengan november 2014. Dimana sampai Desember 2013 total KUR yang tersalurkan sebesar Rp 22.156.210.496 dengan jumlah debitur KUR sebanyak 181 debitur dan pada November 2014 naik menjadi Rp 23.105.726.477 dengan jumlah debitur sebanyak 223 debitur. Pertumbuhan atau kenaikan dana KUR yang disalurkan dari tahun 2013 ke tahun 2014 dilihat dari data tersebut diketahui sebesar Rp 949.515.981 dengan pertumbuhan debitur sebanyak 42 debitur. Kondisi ini diperoleh oleh BRI tidak lepas dari kerja keras dan upaya-upaya strategis yang terus ditingkatkan. Selain itu BRI juga memiliki motivasi tersendiri dengan adanya program KUR yaitu membantu pemerintah dalam meningkatkan usaha sektor riil terutama UKMK, sehingga meskipun dengan kondisi NPL per 2014 ini cukup menghawatirkan, BRI tetap mengupayakan meningkatkan penyerapan dana KUR. Tentu saja pada kondisi saat ini pemberian dana KUR dilakukan dengan seleksi yang lebih ketat terutama melihat dan menganalisa produk usaha yang dijukan dengan dana KUR oleh calon debitur. Contohnya dikatakan oleh staf ADK per akhir tahun 2014 ini calon debitur yang memproduksi benang, tidak direkomendasikan untuk di beri KUR, 
dengan alasan penyumbang terbesar untuk NPL tahun 2014 adalah pengusaha benang.

\section{Net Performing Loan (NPL)}

NPL sampai Desember 2013 menunjukkan kondisi yang baik, dimana NPL hanya sebesar 2,87\% masih jauh dibawah standar yang ditetapkan dalam pengukuran tingkat kesehatan bank sebesar 5\%. Hal ini menunjukkan dari total KUR yang tersalurkan sebesar $\mathrm{Rp}$ 22.156.210.496 hanya sebesar Rp 636.282.180 dengan jumlah debitur sebanyak 5 orang yang dinyatakan kredit bermasalah. Kondisis ini menunjukkan bahwa BRI dalam menseleksi calon debitur dan fungsi pengawasan yang dijalankan sudah baik.

Di sisi lain hal ini menggambarkan bahwa kredit yang tersalur sebesar $\mathrm{Rp}$ 21.519.928.316 dengan jumlah debitur sebanyak 176 menunjukkan kondisi dimana usaha mereka ada perkembangan dari adanya bantuan KUR. Kondisi ini didukung dengan informasi dari AO dan debitur yang lancar pembayaran angsurannya menyatakan bahwa usaha debitur meningkat setelah adanya bantuan dari program KUR BRI untuk pengadaan/penambahan persediaan barang dagangan, penjualan mereka meningkat sehingga berpengaruh terhadap peningkatan omset dan laba kotor yang mereka peroleh, sehingga pembayaran angsuranpun menjadi lancar.

3. Usaha debitur berkembang

Seperti sudah diuraikan pada poin dua, dari data pembayaran yang lancar menurut survei AO dan MP ini menunjukan bahwa usaha para debitur mengalami perkembangan. Dinyatakan juga oleh debitur, hal ini memang dialami oleh debitur bahwa mereka mengalami peningkatan omset dan laba, seperti yang dialami oleh informan debitur yang satu ini (tidak mau disebutkan namanya) menunjukkan bahwa omset tahun 2013 Rp 1.204.107.961 dengan laba kotor sebesar
Rp 164.656.391 dan pada tahun 2014 meningkat menjadi sebesar $\mathrm{Rp}$ 1.475.000.000 dengan laba kotor yang diperoleh sebesar Rp 234.220.051.

4. KUR dijadikan oleh BRI sebagai embrio dari Kredit Ritel komersial, artinya debiturdebitur yang sudah bagus pada tingkat KUR akan direkomendasi untuk naik menjadi debitur Kredit Ritel Komersial, ydimana kredit komersial ini akan lebih menguntungkkan bagi pihak bank arena dari segi tingkat suku bunga juga lebih tinggi. Terbukti pada tahun 2013 mulai ada debitur KUR ritel yang naik ke Kredit Ritel Komersial setidaknya 1 debitur, dan pada tahun 2014 ada 4 debitur. Kondisi ini diharapkan pada tahun 2015 terus meningkat.

\section{Tingkat Keberhasilan Program KUR Mikro}

Seperti halnya yang disampaikan oleh Tim Pemutus KUR Ritel beserta staf lininya, maka Tim KUR Mikro pun yaitu AMBM dan kepala unit (informan Kepala Unit BRI Cicalengka dan Kepala Unit BRI Maruyung) serta mantri menyatakan hal senada mengenai indikator dalam mengukur keberhasilan KUR. Beberapa indikator yang dimaksud dalam mengukur keberhasilan program KUR Mikro yaitu

\section{Tingkat Penyerapan KUR}

KUR Mikro merupakan program KUR yang disalurkan melalui putusan kepala unit BRI. Kantor unit BRI yang ada didalam organisasi Kantor Cabang Majalaya sebanyak 15 kantor. Total penyerapan dana KUR Mikro dari 15 kantor unit per Desember 2013 mencapai Rp 48,1 M dengan jumlah debitur sebanyak 7.526 dan pada bulan Oktober 2014 naik menjadi sebesar Rp 61,7 M (outstanding) dengan jumlah debitur sebanyak 9.173 (existing). Dari 15 kantor unit, penulis ambil 2 kantor unit untuk dilihat tingkat penyerapannya, diantaranya adalah kantor unit BRI Cicalengka dimana 
sampai Desember 2013 total KUR yang dirsalurkan sebesar Rp 2,312 M (outstanding) dengan jumlah debitur KUR sebanyak 527 debitur dan pada November 2014 naik menjadi Rp 2,894 M dengan jumlah debitur sebanyak 571 debitur. Pertumbuhan atau kenaikan dana KUR yang disalurkan dari tahun 2013 ke tahun 2014 dilihat dari data tersebut diketahui sebesar Rp 582 juta dengan pertumbuhan debitur sebanyak 44 debitur.

Kantor unit kedua yaitu maruyung sampai Desember 2013 total KUR yang dirsalurkan sebesar Rp 4 M (outstanding) dengan jumlah debitur KUR sebanyak 385 debitur dan pada November 2014 naik menjadi Rp 4,7 M dengan jumlah debitur sebanyak 822 debitur. Pertumbuhan atau kenaikan dana KUR yang disalurkan dari tahun 2013 ke tahun 2014 dilihat dari data tersebut diketahui sebesar Rp 700 juta dengan pertumbuhan debitur sebanyak 325 debitur.

Kondisi ini menunjukkan bahwa kedua kantor unit ini ada upaya dalam meningkatkan penyerapan dana KUR oleh UKM pada tahun 2014.

\section{Net Performing Loan (NPL)}

NPL sampai Oktober 2014 secara Total untuk 15 kantor unit menurut informasi dari AMBM sebesar 1,34\%. Ini menunjukan kondisi yang sangat baik. Artinya dari total Rp 61,7 M hanya sebesar Rp 826,780 juta yang masuk kedalam kategori macet. Dengan demikian BRI sangat berpeluang untuk mendapatkan pendapatan dari sumber bunga kredit yang cukup tinggi.

Sementara NPL atas KUR Mikro di Kantor unit Cicalengka tahun 2013 sebesar 1,15\% dan pada tahun 2014 naik menjadi 2,04\%. Demikian pula yang terjadi pada kantor Unit BRI Maruyung dimana NPL mengalami kenaikkan dari 2013 ke 2014 yaitu dari sebesar $0,29 \%$ menjadi $2,1 \%$.

Secara umum, kondisi NPL yang naik masih bisa dikategorikan baik dilihat dari standar kesehatan bank menurut metode camel yaitu 5\%. Namun demikian tetap harus diwaspadai jangan sampai pada tahun 2015 terus naik. Dari internal BRI sendiri memiliki standar NPL yang baik yaitu di bawah 3\%.

Kewaspadaan bisa ditingkatkan dengan mengenali penyebab naiknya NPL tersebut. Hasil wawancara dengan masing-masing Kepala Unit, mereka mengatakan bahwa debitur kantor unit cicalengka untuk kategori macet, bukan karena pribadi debitur yang tidak baik namun karena adanya kejadian yang diluar kemampuan manusia yaitu terjadinya kebakaran pasar tradisional cicalengka, pasca kebakaran pasar beberapa debitur tempat usahanya terbakar. Sementara supplier menjadi tidak ada konsumennya, sehingga mereka tidak memiliki penghasilan untuk beberapa waktu dan berakibat terhadap macetnya pembayaran kredit. Sedangkan di kantor unit BRI Maruyung NPL naik disebabkan oleh adanya usaha tani beberapa debitur yang gagal panen. Selain itu sebagian besar petani memasarkan hasil taninya ke Jakarta, sementara semenjak musim hujan di tahun 2014 Jakarta dilanda banjir, sehingga pemasaran tersendat, dan pendapatan dari penjualan pun menjadi sangat berkurang.

Menurut para kepala unit kedua kantor unit yang disurvei, mereka melakukan beberapa upaya dalam penurunan NPL, yaitu melakukan penagihan dengan pendekatan kekeluargaan dan restrukturisasi kredit yang meliputi perpanjangan waktu, keringanan suku bunga dan penambahan plafon. Restrukturisasi bisa diambil salah satu ataupun dikombinasi. 
3. Usaha debitur berkembang

Dari tingkat NPL yang baik, ini menunjukkan sebagian besar debitur mengalami perkembangan dalam usahanya, atau dengan adanya bantuan KUR, minimal mereka mampu bertahan dalam menjalankan operasional usahanya sehingga mampu dengan konsisten membayar angsuran dengan tepat waktu dan tepat jumlah.

\section{SIMPULAN}

Hasil analisa mengenai implementasi program KUR di BRI Kantor Cabang Majalaya, penulis dapat menyimpulkan beberapa hal:

1. Pelaksanaan program KUR di BRI Kanca Majalaya cukup baik, prosedur pelaksanaa yang dilakukan pada prinsipnya sudah sesuai dengan UU Perbankan dan Surant Edaran BRI. Tidak kalah penting adalah mengenai waktu yang dibutuhkan dalam proses pemberian KUR cukup singkat yaitu secara keseluruhan dengan kondisi ideal cukup memerlukan waktu selama 7 hari untuk KUR Ritel dan maksimal 5 hari untuk KUR Mikro.

2. Penyaluran program KUR baik KUR Ritel maupun KUR Mikro dapat dikatakan cukup berhasil. Hal ini ditunjukkan dengan adanya pertumbuhan penyerapan dana KUR yang cukup tinggi, dan NPL yang relatif rendah serta tumbuhkembangnya UKM yang dibantu dengan dana KUR.

\section{DAFTAR PUSTAKA}

Ismail, 2010, Manajemen Perbankan, Dari Teori Menuju Aplikasi, Kencana: Jakarta

Kasmir, 2010, Dasar-Dasar Perbankan. Rajawali Pers: jakarta

Keputusan Menteri Koordinator Bidang Perekonomian Nomor : KEP07/M.EKON/01/2010 Tentang Penambahan Bank Pelaksana Kredit Usaha Rakyat,

Keputusan Deputi Bidang Koordinasi Ekonomi Makro dan Keuangan, Kementerian Koordinator Bidang Perekonomian Nomor : KEP-01/D.I.M.EKON/01/2010 tentang Standar Operasional dan Prosedur Pelaksanaan Kredit Usaha Rakyat.

Lukman, 2005, Manajemen Perbankan, Ghalia Indonesia: Bogor

Mandala, 2004, Uang, Perbankan, dan Ekonomi Moneter, FakultaS Ekonomi Universitas Indonesia: Jakarta

Perjanjian Kerja Sama antara Bank Pelaksana dengan Lembaga Penjaminan

Surat Edaran Direksi BRI Nose S.08DIR/ADK/03/2010 tanggal 4 Maret 2010 Tentang Kredit Usaha Rakyat (KUR) Ritel

Surat Edaran Direksi BRI Nose S.08dDIR/ADK/03/2010 tanggal 23 Mei 2013 Tentang Revisi Keempat Atas Ketentuan Kredit Usaha Rakyat (KUR) Ritel.

Undang-Undang Nomor 10 Tahun 1998 tentang Perbankan 